\title{
WHAT IS THE POSITION OF AGRITOURISM ON THE WALLOON TOURIST MARKET?
}

\author{
Charline Dubois ${ }^{1}$, Serge Schmitz ${ }^{2}$
}

Received 20 November 2012; Accepted 20 September 2013

\begin{abstract}
With its marginal practices and diversified services, agritourism is a complex subject of study. In some European rural areas it is seen as a smart diversification solution. Even though agritourism is rather weak on the Walloon tourist market level, it is important for farmers for whom it is often a means of supplementary income. Based on crossed data concerning potential tourists, local tenants, privileged witnesses and promotional information, the position of agritourism on the Walloon tourist market is analysed. It is shown that agritourism is a multiple micro-niche market primarily complementary to other sources of tourist supply. This paper underscores how the assets of demand, of the region and of the farm all shape agritourist diversification. Instead of providing a standardized well-known product, agritourism in Wallonia is richly diverse, which creates difficulties in branding this tourist market sector.
\end{abstract}

Key words: agritourism, tourism on the farm, Wallonia, niche markets, rural tourism.

Résumé: Pratiques marginales et services diversifiés, l'agritourisme est un sujet d'étude complexe. Dans certaines zones rurales européennes on le voit comme une solution magique de diversification. Même s'il est relativement faible sur le marché touristique wallon, l'agritourisme est important pour les agriculteurs pour qui c'est souvent une source de revenus complémentaires. Basée sur des données croisées concernant des touristes potentiels, des tenanciers, des témoins privilégiés et des informations promotionnelles, la position de l'agritourisme sur le marché touristique wallon est analysée. On montre que l'agritourisme est un marché de multiples micro-niches, complémentaire d'autres offres touristiques. L'article souligne que les caractéristiques de la demande, de la région et de la ferme influencent la diversification agritouristique. A la place d'un produit standardisé bien connu, l'agritourisme est multiple en Wallonie. Cette diversité et cette richesse induisent des difficultés à promouvoir cette branche du marché touristique.

Mots clés: agritourisme, tourisme à la ferme, Wallonie, marchés de niche, tourisme rural.

\footnotetext{
${ }^{1}$ Charline Dubois, PhDs. National Research Fund, Luxembourg \& Université de Liège, Département de géographie, Laplec, Allée du six Août, 2, B-4000, Liége, Belgium; charline.dubois@ulg.ac.be

2 Prof. Dr. Serge Schmitz, Université de Liège, Département de géographie, Laplec, Allée du six Août, 2, B-4000, Liége, Belgium; S.Schmitz@ulg.ac.be , +32 43665629
} 


\section{Introduction}

Current diversifications in the agricultural domain are answers to the increasing pressures and difficulties that farmers encounter. Industrialization, specialization, the concentration of activities and international concurrence have compelled farmers in some European regions to diversify their agricultural activities in order to diversify their incomes. This adaptation is one answer to the need felt by contemporary farmers to reconsider their work for their farm's survival. For this reason, welcoming tourists on the farm was, for some of them, a "magic" solution, a secondary activity with roots in agricultural activities (Busby \& Rendle, 2000; Roberts \& Hall, 2001; Nilsson, 2002; Sharpley \& Vass, 2006; Philips et al., 2009; Tew \& Barbieri, 2012). Recently, with the creation of new agritourist enterprises and the diversification of agricultural activities, agritourism is increasingly interrelated to tourist supply. Today, agritourism is more often an alternative activity than a complementary activity to agriculture (Roberts \& Hall, 2001; Nilsson, 2002; Lescureux, 2004; Marcotte et al. 2006; Yang et al., 2010; Forbord et al., 2012).

Nevertheless, agritourism, or in broad terms, having a good time on a working farm, is, and probably will remain, a marginal practice in terms of its share of tourist overnights and day visits. This marginality is increased by the diversity of services that may be included in agritourism. Nowadays, agritourism is a complex subject of study with differing definitions between regions, legislation, and authors on the subject (Clarke, 1996; Busby \& Rendle, 2000; Fleischer \& Tchetchik, 2005; Marcotte et al. 2006; Philips et al., 2009; Sznajder et al., 2009). Each farm has different free resources (room, space, food, manpower, landscape, fresh air, fresh water, silence, machinery, animals...) that could be valorised by agritourism. Béteille (1996) already added that the different developments are influenced by the relative place of the agritourist diversification in the agricultural milieu and by each region's tourist potential: intensity of the tourist demand, tourist volume and proximity of urban populations. Opportunities are numerous and lead to various developments: accommodation, transformation of agricultural products, direct sale, recreational and relaxation activities, sport activities, health care and rehabilitation activities, observation of agricultural production... (Clarke, 1996; Busby \& Rendle, 2000; Marcotte et al. 2006; Philips et al., 2009; Sznajder et al., 2009; Forbord et al., 2012). Most of these activities use the farm capital. The farm should be the basic entity providing tourist services that take advantage of the cultural, social, environmental and economic resources of the farm and its surroundings (Cawley \& Gillmor, 2008; Yang et al. 2010). Yet this appealing idea of diversifying the farm to welcome in tourists to enjoy the assets and resources of the farm usually leads to a rejection of one of the two activities, because modern farming and professional tourism do not fit so simply together (Dubois \& Schmitz, 2012).

Despite its marginality and diversity agritourism is worth analysing because it is important for many farmers but also because developments in agritourism have challenged its multifunctionality and demonstrated its limits (Van der Ploeg et al., 2000). This present research has chosen to stress the geographical approach of the phenomena. It examines the influence of local rural capital and focuses on the adaptation of agritourist development to the geographical setting. Embeddedness in the local context and the competition and search for a niche in the tourist market need to be explored to understand the position of agritourism in the tourist market and the diversity of its products.

Therefore this paper tackles the question of the position of agritourism in the tourist market. First, the number of agritourism developments and overnights in farm tourism in Wallonia is explored. Second, the paper stresses the diversity of farm diversifications related to farm tourism, including in the relatively small region of Wallonia. Third, the links between type of farm tourism and both farm structure and regional assets are considered. Last, the paper suggests that, depending on several factors listed here, agritourism in Wallonia, and probably in many regions, represents, or more precisely could represent, multiple micro-niches rather than a single micro-niche market. By studying the Walloon case, this paper aims to contribute to the knowledge of agritourist diversifications, to suggest a model of agritourism opportunities according to regional assets, and finally to discuss the uniqueness of this kind of accommodation in the tourist supply. 


\section{Agritourism: a question of definition}

The diverse perspectives of farmers, tourist actors and researchers make it difficult to propose one unique and synthetic definition of agritourism. Even if the farming environment seems to be the basis of most of the definitions, authors and actors pay more or less attention to the balance between tourist activity and agricultural activity, to the immersion in farming life that can include active participation in agricultural work, or to the business orientation of the tourism accommodation. Moreover, agritourism is not the only tourist activity to be related to agriculture, forestry, food processing, host community and rural areas. Ecotourism, green tourism, safaris, wine tourism, cultural tourism and, of course, rural tourism share the same assets (Busby \& Rendle, 2000; Nickerson, 2001; McGehee \& Kim, 2004; Fleischer \& Tchetchik, 2005; Marcotte et al. 2006).

Austria, Germany, England and France are the traditional countries dominating the sector of holidays on the farm with "small" farms, urban customers and a mountainous pool of tourists. There and in Belgium, farm tourism was an old practice that fell into disuse in the last century with the development of standardised tourist resorts and packaged leisure services. It came back on the tourist scene when more emotional and meaningful experiences began motivating travel and when the car made it possible to leave traditional itineraries. For urban citizens disconnected from agriculture, there is an increasing interest in rediscovering the charms of the countryside and a questioning about where food comes from and how it is produced (Béteille, 1996; Disez, 1999; Busby \& Rendle, 2000; Novelli, 2005; Sznajder et al., 2009; Marsat, 2011).

So, are there unique aspects to agritourism? According to past authors on the subject, agritourism is marked by certain particularities. First there is its practical aspect and the possibility of discovering the farm with its food production and its rural family life. Second there is its cognitive aspect with a chance to learn about culture and customs. Finally there is its emotional aspect with the chance to have direct contact with animals and to experience the atmosphere of the countryside (Sznajder et al., 2009). Tourists are increasingly interested in new forms of tourist products: variations that let them be closer to nature and tranquillity, learn new things, profit from a family atmosphere, as well as many other features not found in urban tourism or in mass tourism. There is a growth in demand requiring smaller-scale, segmented, specialised, sophisticated and also more flexible services (Buck, 2000; Novelli, 2005). A tourist niche becomes an asset in itself, and marginal practices may take advantage of their situation. Furthermore, agritourism could be seen as a way of allowing the expression of identity, as a real experience that awakens the six senses (including proprioception), and includes both social interactions and potentially rich cognition aspects (Ladwein, 2012).

Agritourism is thus a meeting, sometimes fragile, between the tourist and the agricultural sectors. The diversification into tourism is an important change for the involved farm family: it demands new skills and competencies and may influence mentality and identity (Brandth \& Haugen, 2011). It corresponds to a particularly small segment among large market sectors called niche in counter-point to mass-tourism. More precisely, in the rural tourism niche product, agritourism can be defined as a "micro-niche". Agritourism tends to develop itself in the tourist market and to adapt to both the competition with other tourist activities (tourist niche) and the geographical settings inside the countryside (ecological niche) (Odum 1959; Kazakopoulos \& Gidarakou, 2003; Ainley \& Smale, 2010). This ecological niche metaphor refers to an optimum location characterised by environmental factors affecting species in the presence of competitors (Novelli, 2005). Of course in the case of tourist diversification on a working farm the location of this tourist activity is part of the constraints: farmers cannot choose the location of this new activity because the farm already exists in a delimitated space. Consequently the services offered will be strongly influenced by this location.

\section{Methodology}

The purpose of this study is to offer elements answering the question of the position of agritourism in the Walloon tourist market. As will be mentioned below, official statistical data concerning agritourism is lacking. To answer the different questions emphasized above, 
a crossing of data collected through investigations and interviews carried out in Wallonia in 2011 and 2012 is used:

(a) 19 on site life-histories of local tenants including a presentation of the farm and of the agritourist development history, underlining the motivations, the challenges, the implication of their activities and the impact on the neighbourhood.

(b) 13 interviews of privileged witnesses chosen from local to regional scale levels, in the political and administrative areas of the agricultural and tourist domains in order to clarify the different concepts and to position the different spatial, temporal and thematic frameworks.

(c) Survey of 230 potential tourists carried out in tourist poles (Liège and Bouillon) with the aim of studying the tourist demand and characterizing both tourists and agritourist profiles. The survey analyses the representations of tourists regarding agritourism.

(d) Content analysis of promotional folders and websites produced by tenants and tourist organizations.

The life histories and the interviews were recorded, transcribed and coded using NVIVO ${ }^{\circledR}$ software. The answers to the survey were coded in a spreadsheet and analysed via contingency tables.

\section{Agritourism in the Walloon tourist market}

Wallonia (one of the three federal Regions of Belgium with 3.5 million inhabitants) counts globally each year (2009-2010 data) approximately $8,500,000$ tourist overnights. It is a European crossroads where tourists stop in transit towards destinations further south as well as a proximity tourist destination for the populations of Belgian, Dutch and German cities (Schmitz, 2013; Eurostat, 2012). The destination "Wallonia" is a juxtaposition of green tourism, of wellbeing tourism, of family tourism and, for urban youth, of adventure tourism. Tourists come to Wallonia for short stays from neighbouring countries. The "warm welcome" is the brand. Based on a rich material and immaterial heritage including gastronomy, green nature and diversity of landscapes, the promotion particularly stresses outdoor activities in nature even though Wallonia also promotes business tourism.

In Wallonia, agritourism began officially in 1976 with pioneer farmers who launched their diversification and benefited by framing associations coming from Walloon agricultural unions. In comparison to other European regions such as Slovenia, Austria or Spain it is a suburban agritourism that is developed in Wallonia, Nevertheless agritourism remains a poorly studied subject in Wallonia. There is no approved definition and no efficient data for analysing the practices.

\section{Marginal and diversified practices}

Due to the membership of agritourism in different tourist and agricultural matters, and therefore in different policies, it is difficult to quantify agritourist development precisely. When the Walloon tourism statistics include agritourism in the category of rural tourism, the Walloon agricultural statistics do not mention it. So no official statistics concern only agritourism. Moreover, inconsistencies exist in some statistical data (differences between the official data and estimations), resulting in a need for precise data about the number of agritourist establishments in Wallonia to be estimated again. This problem confirms the lack of conceptualization of agritourism (there is no precise definition and many different activities are included under this term) as well as the low interest in the practice from both the political and administrative point of view. Nevertheless some trends in agritourism can be offered on the basis of non-profit association activities, even if all the farmers are not necessarily affiliated with an organization of advice and promotion, such as Accueil champêtre en Wallonie or Gîte de Wallonie.

In 2007 "rural tourism" represented about 1,900,500 overnights, accounting for $20 \%$ of tourist overnights in Wallonia. As there exist in total about 4,600 different official tourist establishments in Wallonia, the number of agritourist establishments indicates a ratio of $5 \%$ of the global 
supply. It is important to keep in mind that in Wallonia the percentage of labour in agriculture is approximately $2 \%$ of the labour force and that the total number of farms is about 14,500 units with an average size of 47 ha (Eurostat, 2012). In 1997209 agricultural tenants (1\% of the farms) were involved in agritourism, offering gîte, bed-and-breakfast and camping on farms. Fifteen years later, in 2012 there are officially around 380 agritourist tenants. Even though agritourist owners increased over these last fifteen years, the ratio of farmers involved in agritourism activity is still small: only $3 \%$.

From a legal point of view, the Walloon tourist Code lists different points such as the maximum authorized number of rooms and gîtes, or self catering apartments, (five B\&B and five gîtes), the number of opening months (at least four months including summer school holidays), remarks on how to be welcoming and positive aspects of accommodations, some particular rules for camping on a farm, classification criteria and remarks concerning proposed meals. Of course the code also lists the different kinds of accommodation. And because agritourist activities are not numerous, structures of assistance also integrate other rural accommodations into their typologies. In Wallonia, the gîte on a farm is usually in an independent and autonomous building on an active farm or in close vicinity to it. The bed-and-breakfast on a farm is an accommodation in the tenant's family house on an active farm. The "table d'hôtes" is a service exclusively for bed-and-breakfasts that consists of meals composed of local and regional products, served at the table of the tenant's family. As far as camping on a farm is concerned, it involves campsites organised by a farmer on one of his fields, and it cannot include residential caravans. Gîtes, bed-and-breakfasts and "table d'hôtes" on a farm are included in the "rural tourism" category.

At first sight, the supply seems diversified. However the gîtes remain the main trend with around 435 gîtes in 2011 against 265 in 1997 (one farmer may proposes more than one gîte on his farm, and there is no restriction regarding the number of beds included in each gite). Around $75 \%$ of Walloon agritourist tenants have chosen at least one gîte creation as rehabilitation of an old building or of one part of it. It is mainly a choice based on time constraints for the farmers and facilities for welcoming tourists. During the life histories several farmers told us: "It was quite easy to develop a gite on our farm: we give them the key on their arrival, and we get it back again at the end of their stay... We don't need to serve them". In the last decade, the number of gîtes in the category of more than 15 persons increased a lot: from 20 to around 65 gîtes.

A second point worth noting is the diversification of activities proposed by farms. While gîtes and bed-and-breakfasts are the two main services, there has been a development of thematic labels that aims at attracting a specialised element of the agritourist supply. Beside the labels "Panda" (label of the WWF) or "Patrimonial Assets", different activities such as "Exploring nature", "Horseback riding" or "Fishing" brand accommodations on farms. Specific services are specially proposed to families or to business tourists. Services as diverse as agrogolf, barbecues, children's birthday parties, team building activities or massage may enrich the panel of proposed activities. The renting of large rooms on the farm for weddings and family gatherings are other possibilities for developing an agritourist supply. Educational farms are also an attractive product, particularly for schools. Finally, some activities are linked to the sale and discovery of local products, even if the product is not dominant in Wallonia. Agritourism in Wallonia, then, is increasingly diversified. Four main axis can be identified: leisure, accommodation, food and education

\section{Geographical distribution of agritourism}

According to Van Hecke et al. (2010) as well as the different folders and tourist maps produced by administrations and tourist organisations, it is possible to analyse the location of agritourist activities. Although agritourist accommodations are less represented in the Lorraine (extreme south region of Belgium in the Paris Basin identified with its repetitive landscape with cuesta), in the German speaking part (in the east of the province of Liege) and at the edge of urban agglomerations (less than $15 \mathrm{~km}$ ), agritourist accommodations in Wallonia can be found everywhere (Figures 1 and 2). The Ardennes (part of the Rhenish Massif composed of forests and often chosen by tourists for its natural attractions) and the Condroz region (located just to the north of the Ardennes and known for its landscape of little hills and valleys) concentrate 
the supply. Nevertheless agritourist accommodations also exist in regions without any other tourist accommodations, including regions with high agricultural productivity.

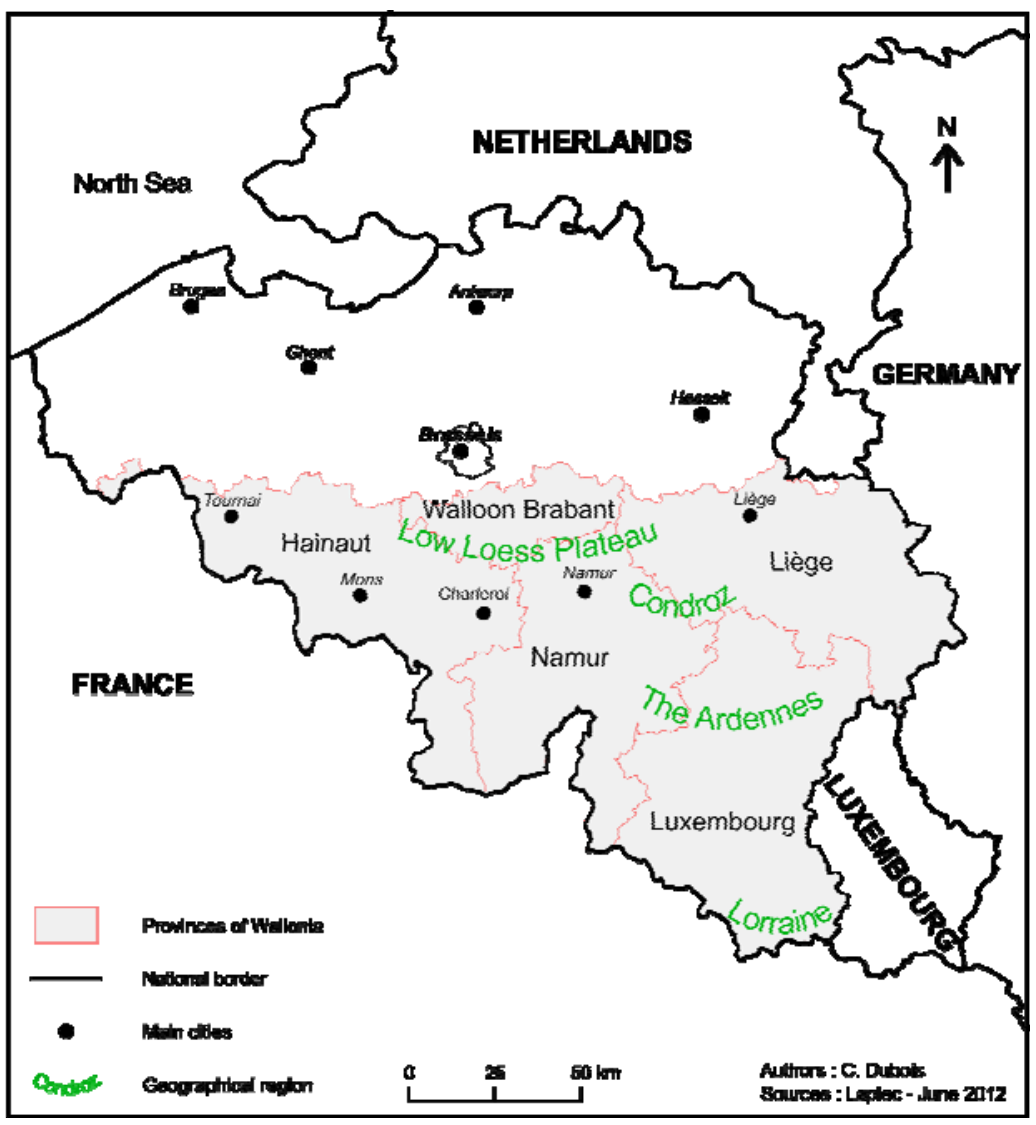

Fig 1. Walloon geographical regions and provinces.

\section{FARM TOURISM IN WALLONIA}

2012

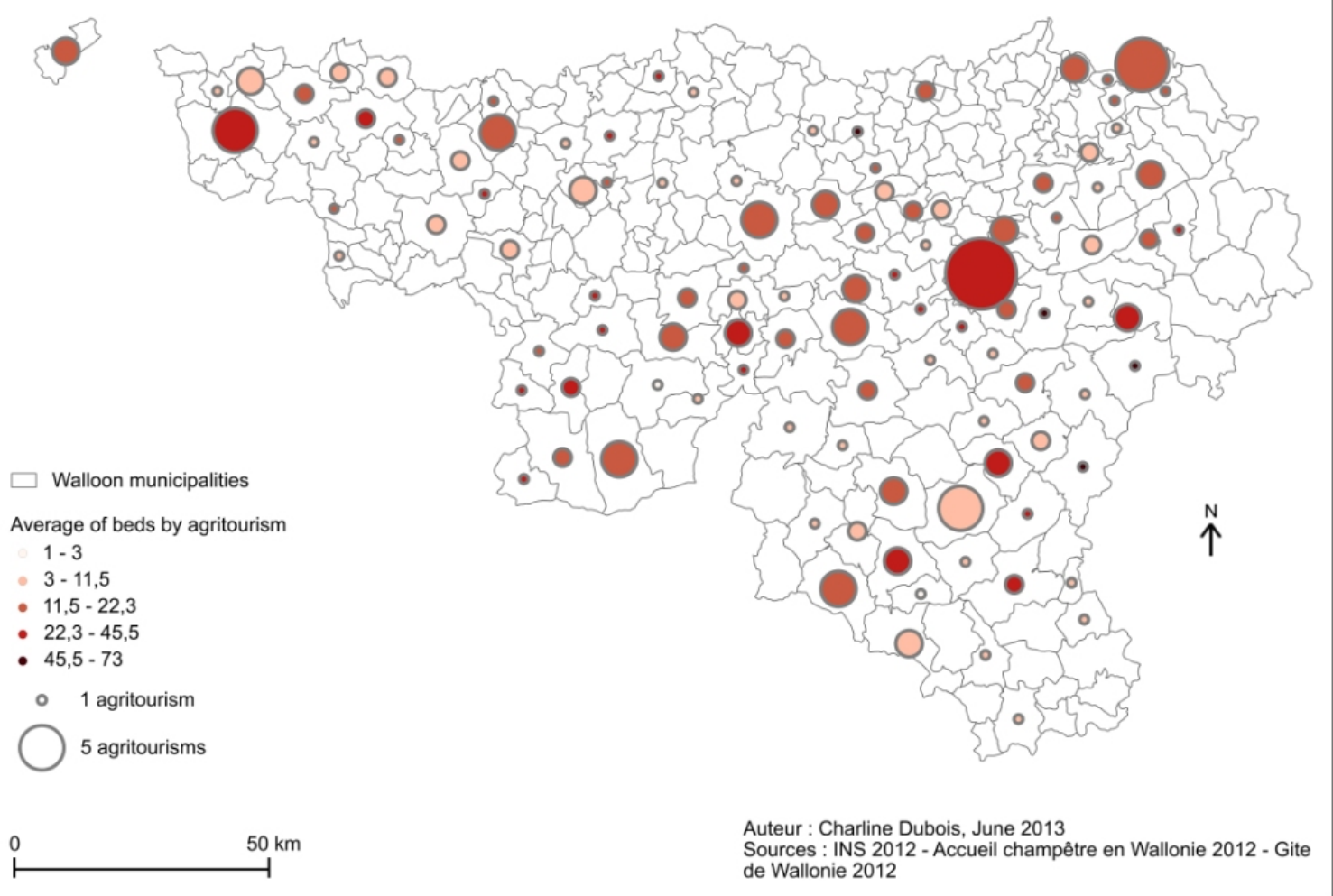

Fig 2. Numbers of beds in Walloon agritourism in 2012. 
Different geographical factors influence the frequenting and the specialisation of agritourism development in Wallonia. Agricultural and tourist data stress some contrasts. Many tourist managers say that the regional potential needs to be recognised in order to adapt the agritourist diversification to regional assets. On the one hand, the resources of agritourist activities may be diverse, and several elements may become a basis for a diversification. On the other hand, the relative proximity of tourist home residences or of tourist flux generate opportunities.

Several geographical factors influence the development of agritourism in the Walloon countryside. The local landscape enhances the heterogeneous character of agritourist development in Wallonia. For example, ploughed fields in the north of Wallonia and the Ardennes forests are quite different regarding tourist perspectives. The choice of tourist diversification should take into account the geographical setting and avoid replicating initiatives developed in a totally different context. In the Ardennes forests, agritourists may turn towards green nature and adventure sports. The surroundings of the farm would be the main asset. Among the ploughed fields, the farm itself with its large building may be the main asset. These historical buildings serve well for gatherings of friends and family, wedding parties or conferences. Moreover a location near cities, near an airport and near tourist spots can also be added value and the reason for the stay. For instance, farms located on a large ploughed plateau and in a suburban area could take advantage of the accessibility to potential markets and the supply by specializing in farm rooms renting out for events or local products sales to customers nearby. Otherwise touring and sightseeing could be the reason for the stay thereby reducing the advantage of being a working farm. Because people often choose first the place where they want to tour around, and then select their accommodation, agritourism is often more a new accommodation alternative in the region than a new destination itself.

The size of the farm and its specialization also influence the development of agritourism. Indeed, when the farm is big enough there is no need and no time for agritourist diversification. Self-catering apartments will be preferred to more time consuming activities. But if the farm is too small, there are no means (financial, spatial, and mechanical) for agritourist development. The presence of animals or of orchards, or the possibility of finding a special gastronomy or diverse local products on the farm may be appealing for tourists. Nevertheless, both the size and the specialization of the farm are most of the time strongly influenced by the characteristics of the agricultural region.

The following diagram (Figure 3) shows a first attempt at linking typology of Walloon agritourist products, type of countryside and geographical setting. This approach cannot be limited to physical aspects as other general factors influence the presence of particular agritourist products or their levels of development or quality. They are additional filters to understand and to suggest diversification adapted to the local context. Political incentives, competitiveness of agriculture, level of modernization, tradition of hospitality should complete the explanatory model.

The explanatory model links the type of agritourist diversification and the geographical settings. Landscape characteristics, rural economic specialization, vicinity of tourist spots, and accessibility shape the geographical context that influences the type of diversification. Agritourism development put in first a green and natural gradient that reinforces itself with forests and meadows. This gradient evolves to an agritourism based on discovering the landscape by the means of small trails or extreme sport. In places where agriculture is deeply specialized, such as growing industrial crops, other alternatives such as renting rooms for family banquets, parties and weddings or discovering farm products, if the market is not too far away, will be found. The vicinity of city centres or of traffic connections (road, train, etc.) allows the development of short stays or business tourism, especially in a countryside where a mixed agriculture is developed. 


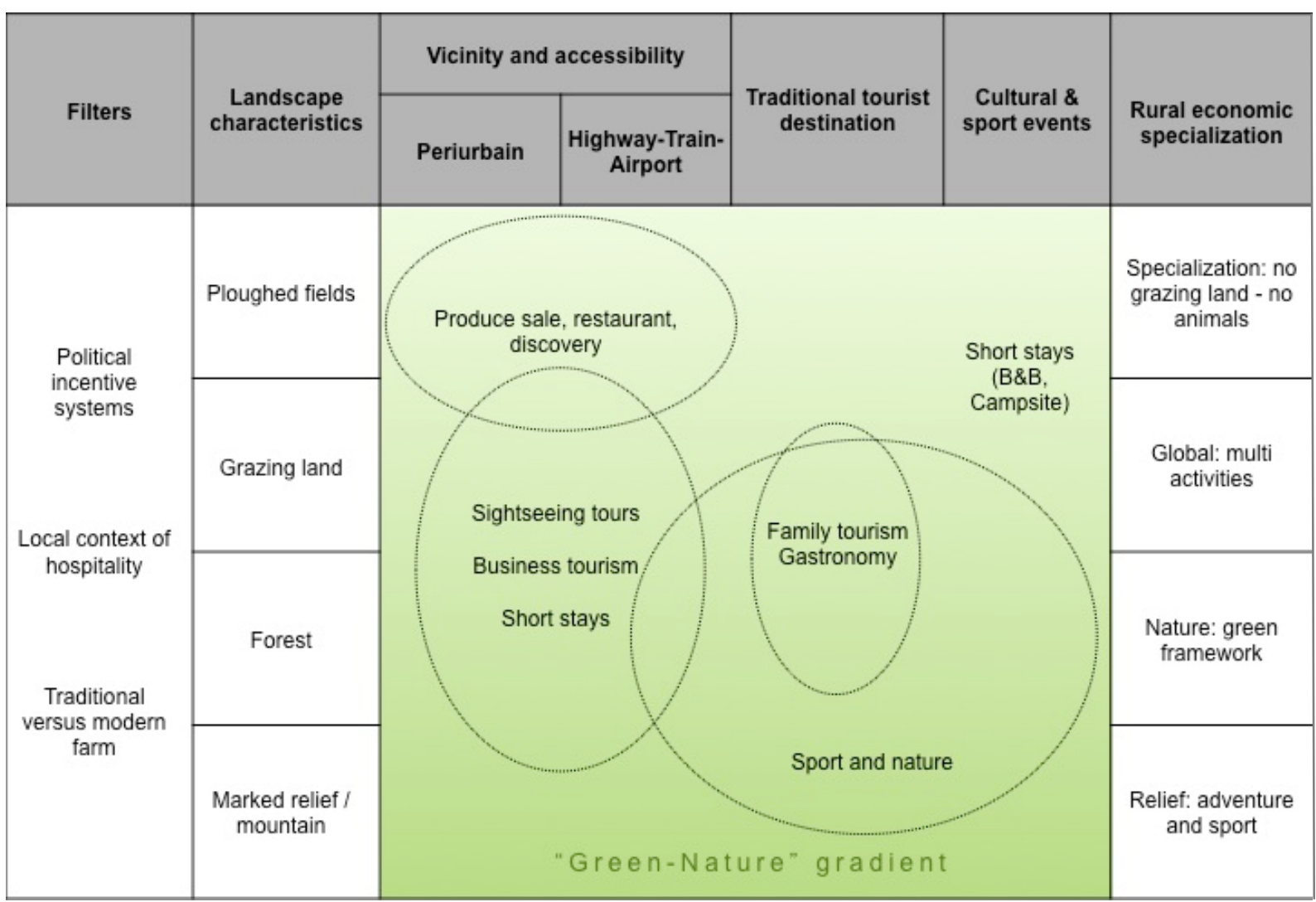

Fig 3. Agritourist products according to the type of countryside, the geographical settings and the filters.

These links between types of agritourism diversification and types of countryside suggest the idea that agritourism must be analysed not only as a tourist niche but also as an ecological niche. The tourist farm has to both find a place in the tourist market and develop embeddedness in the local and regional context.

\section{Influential market demand and competition}

First, the interviews and life histories enlighten us that an important share of the overnights in agritourism in Wallonia are not directly linked with the activities of the farm, but only to the location and the relatively modest prices for accommodation. In comparison to other kinds of accommodation, agritourism in Wallonia is often located in places where there is no other possible supply or, when that is not the case, there is no other supply at the same price. Outside of the core business, but important from an economic point of view, these locations are interesting for workers and businessmen and women who work on particular building/working sites and who would like to accommodate themselves with quite low prices. Several investigated farms regularly host these guests during the week and recreational tourists during the weekend.

Besides the accommodation of workers during the week (clientele that was, most of the time, not expected in the original business plan) farmers are frequently among the few to offer the contact with nature and animals, with the rural way of life, with knowledge of the farmer's work, which meet the contemporary interests of tourists: a real experience with authentic contacts, close to a green environment. The farm is thus one destination due to its particular resources: most of them have at least one tractor and small animals that will be appreciated by children visiting the farm. The development of educational farms and of farms evolving as leisure places, for example, agri-entertainment (Ainley \& Smale, 2010), is dependent on these particular resources. Less frequently, the farm is chosen as a destination for consuming or purchasing local products. Unfortunately, the ultra-specialisation of Walloon agriculture does not allow the farm to offer a broad assortment of farm products. The small number of restaurants on farms demonstrates this fact. Agritourism is also composed of activities linked with the soil, for example golf activities on the farm, which involves playing through the meadows and 
sometimes with cows as spectators. In the end, agritourism, compared to other tourist activities, offers tourists the certitude they will be spending time in an isolated natural milieu. These examples and explanations confirm the uniqueness of agritourism in Wallonia, due to its practical, cognitive and emotional dimensions.

Agritourism diversifications have to find a market and then take into account both the demand and the presence of other accommodations. The analysis of the representation of agritourism shows a rather precise view of agritourism by potential tourists that is not so easy to find in practice. This representation may explain successes and failures; it also indubitably influences the choice of diversification and its evolution. The representation of agritourism reinforces the uniqueness of agritourism, however, it is sometimes fairly distant from the realities of contemporary agricultural life.

During the survey, the people questioned $(n=230)$ suggested various components of their definition of agritourism. They mentioned learning about the agricultural world (and so the importance of staying on an active farm), the presence of animals, the accommodation, participation in the activities of the farm and the tasting of farm products. The components of nature, of countryside, of an adapted tourism for children, of personal hospitality and of quietness complete the picture.

Potential tourists often mention participation in activities on farm. They imagine, especially if they do not have experience in agritourism, being able to take part in the farmer's work. However, they do not understand the dangers, technical sophistication and, sometimes, the painfulness of agricultural work. Besides participation, the personal hospitality offers an interrelationship that does not exist in hotels. However, even if the company of the farmer is perceived as an included service, time devoted to tourists is necessarily limited by time devoted to agriculture. And this time varies according to the tenants.

Many tourists, especially urban ones, have retained the image of an ancient farm. The agricultural sector still profits from a favourable fictionalized image no longer corresponding to the reality of modern industrial agriculture. Paradoxically, even if the questioned people granted relatively little importance to conveniences such as a swimming pool, the facts show that between two accommodations with equivalent criteria, tourists will choose the accommodation with a higher degree of comfort. The farm has then to emphasize both the traditional look of a farm and a comfort comparable to other accommodations (Dubois \& Schmitz, 2012).

The conveniences of the tourists and the maximized services can therefore reinforce the secondary role of the agricultural activity, relegating the farm to the function of decoration. Then, the combination of desires and constraints may lead to an evolution of the agritourist system where agricultural activity is increasingly distinct from tourist activity. For example, figures 4 and 5 both show two different ways to enter into the farm: the tourist way on the left and the farmer way on the right. This duplication of the farm in itself convinces us of the existence of a decorative show of past agricultural times and thus of a 50-year shift in the knowledge and representation of agritourism. 


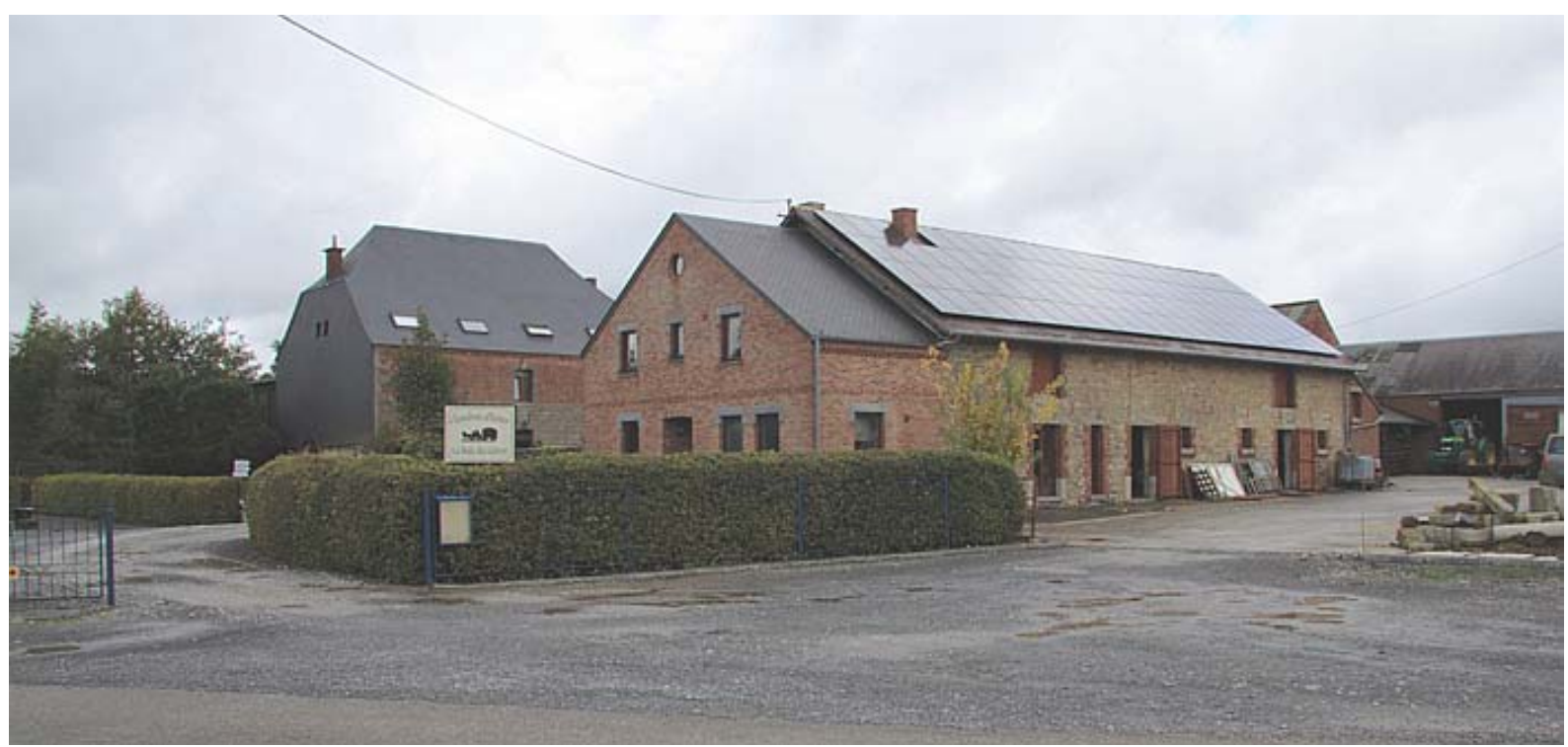

Fig 4. Walloon agritourist farm near Chimay, South-West of Belgium.

So, the nostalgic representation of agriculture and the desire for modern comforts lead to agritourist diversification that deviates from the appealing idea of valorising the working farm. Hence a share of the niche primarily devoted to farm tourism may be occupied by non-working farms. These non-working farms can more easily manage the nuisances of a working farm, create the illusion of being a farm and shape their buildings to tourists' expectations.

\section{Discussion and Conclusion}

Agritourism has numerous definitions, and the links between farming and tourist activity are still being discussed. For the past 35 years, the sector has offered a more specialized supply where innovation allows an adaptation to particular geographical conditions. The wide assortment of agritourist possibilities in Wallonia speaks to both the diversity of the countryside and the creativity of farmers who tend to find a niche in the tourist and leisure sector.

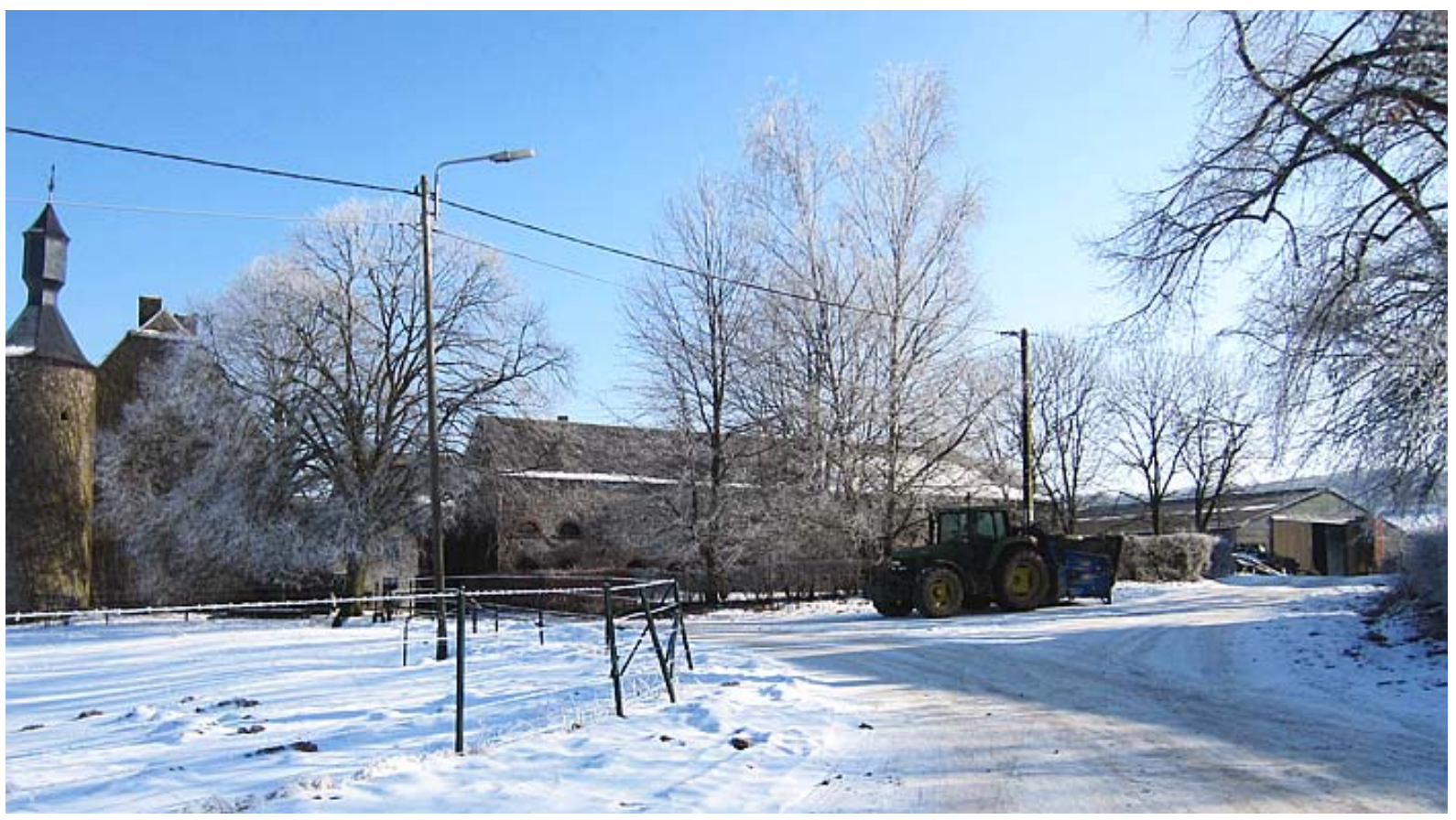

Fig 5. Walloon agritourist farm between Ciney and Marche-en-Famenne, Centre of Wallonia.

Even if agritourism is a minor activity in relation to the global tourist supply in Wallonia, it concerns one thirtieth of the farmers in the region and is therefore worthy of consideration. 
Agritourism is also a relatively important alternative for tourists of one day, in transit, short stays or more. Regarding the position of agritourism, in Wallonia as a micro-niche market, single niche or multiple niches, the analysis shows that tourist farms tend to lean more to the uniqueness of the service due to the constrains of both their location and the degree of complementarity with farming activities. Because agritourism starts from a defined place and location, it has to assume the local and regional settings by valorising the asset of the ecological niche. Yet, demand may lead services down other paths from those first planned. Rather than a particular and single niche for all agritourism units, we observe a growing importance of multiple micro-niche markets, such as business agritourism, fishing agritourism, horsebackriding agritourism or wellness and therapeutic agritourism. The development of particular themes makes the supply more attractive. Everyone may find what he or she is looking for. The micro-niche "agritourism" specializes when tourist market segments and agritourist products need to be developed and marketed in response to the changing nature of global demand.

According to the information on the niche market developed above, agritourism can be seen mainly as a supplementary activity on the tourist market, even if hoteliers, especially in traditional tourist destinations, may think differently. The different rules from administrative and political spheres reinforce the micro-niche characteristics with the result that they are probably a guarantee of no transformation in a denaturized agritourism closer to mass activities.

Nevertheless, the position of agritourism in the Walloon tourism market is fragile, first, because the low number of establishments does not allow it broad recognition as an alternative accommodation or place of recreation. The analysis underscores the reduced share of agritourism both from the tourist establishment and agriculture unit point of view. Moreover it shows that each diversification is unique because of the farm structure and the regional settings. This situation may explain the difficulty of formally defining agritourism for both the actors and the potential tourists. This mix-up concerning the agritourism sector is the second reason the position of agritourism is fragile. It may lead to a dilution of the concept and to the opening of the sector to non-farmers less concerned with embbededness in the agricultural sector.

Side-by-side with a residual tendency to immerse tourists in the farming life, including possible participation in the work of the farm, the main tendency is towards a reinforcement of comfort quality imposed by an increasing demand. But this increase in quality could lead to a denaturising of the product itself. This risk of denaturising the Walloon product exists if the links between the farm and tourism weaken, which could lead to an exit of both the traditional economic and ecological niche. When agritourist spots are reduced to places where the farm has a purely decorative role and agritourism is only exhibition, fair and entertainment, the uniqueness of agritourism is endangered. If the standardization of the agritourism product may help to brand the agritourism sector and facilitate its recognition, it could be at the same time the worst evolution, denaturing a product that needs to be embedded in the farm and its surroundings. Moreover, the difficulties of successfully combining both tourist and farming activities works in favour of the disconnection and the trivialization of farm tourism.

Is there a future for agritourism in Wallonia? Probably yes if the links with agricultural activities are maintained. This paper underscores diverse menaces to these fragile links. Moreover, agritourism is also intimately linked with the survival of family agriculture units, because it is not likely that tourists would enjoy spending free time in industrial plants.

\section{Acknowledgements}

The present project is supported by the National Research Fund, Luxembourg.

References

[1] Ainley, S. \& Smale, B. (2010). A Profile of Canadian Agritourists and the Benefits They Seek, Journal of Rural and Community Development, 5(1), 58-75. 
[2] Beteille, R. (1996). L'agritourisme dans les espaces ruraux européens, Annales de Géographie, 105(592), 584-602.

[3] Brandth, B. \& Haugen, M. (2011). Farm diversification into tourism - Implications for social identity? Journal of Rural Studies, 27(1), 35-44. Doi: 10.1016/j.jrurstud.2010.09.002.

[4] Buck, R. (2000). Rural Tourism and Agri-Tourism: A practical approach to niche tourism, Rural/Agri-Tourism Work Book, AgriTours North America Inc.

[5] Busby, G. \& Rendle, S. (2000). The transition from tourism on farms to farm tourism. Tourism Management, 21(8), 635-642. Doi: 10.1016/S0261-5177(00)00011-X.

[6] Cawley, M. \& Gillmor, D. (2008). Integrated rural tourism: concepts and practice. Annals of Tourism Research, 35(2), 316-337. Doi: 10.1016/j.annals.2007.07.011.

[7] Clarke, J. (1996). Farm accommodation and the communication mix. Tourism Management, 17(8), 611-620. Doi: 10.1016/S0261-5177(97)84224-0.

[8] Disez, N. (1999). Agritourisme. Logiques d'acteurs ou logiques de territoires? Économie rurale, 250 , pp. 40-46.

[9] Dubois, C. \& Schmitz, S. (2012). Un touriste à la ferme: de la thématisation au simulacre. L'expérience touristique, $4^{\mathrm{e}}$ édition des Rendez-vous Champlain sur le Tourisme, Université Libre de Bruxelles.

[10] EUROSTAT (2007). Données démographiques et agricoles. Accessible at: http://epp.eurostat.ec.europa.eu (Retrieved April 2012).

[11] Fleischer, A. \& Tchetchik, A. (2005). Does rural tourism benefit from agriculture? Tourism Management, 26(4), 493-501. Doi: 10.1016/j.tourman.2003.10.003.

[12] Forbord, M., Schermer, M. \& Grießmair, K. (2012). Stability and variety - Products, organization and institutionalization in farm tourism, Tourism Management, 33(4), 895-909. Doi: 10.1016/j.tourman.2011.08.015.

[13] Kazakopoulos, L. \& Gidarakou, I. (2003). Women's Cooperatives in Greece and the Niche Market Challenge. Journal of Rural Cooperation, 31(1), 25-45.

[14] Ladwein, R. (2012). Expérience touristique ou tourisme expérientiel, L'expérience touristique, $4^{\mathrm{e}}$ édition des Rendez-vous Champlain sur le Tourisme, Université Libre de Bruxelles.

[15] Lescureux, F. (2004). Les relations des agriculteurs au territoire au travers de la vente directe et de l'accueil à la ferme. Le cas de la région des Monts de Flandre, Ruralia, 15, 219-225.

[16] Marcotte, P., Bourdeau, L. \& Doyon, M. (2006). Agrotourisme, agritourisme et tourisme à la ferme? Une analyse comparativ., Téoros, 25(3), 59-67.

[17] Marsat, J.-B., Bonniot, A., Bouchaud, M. \& Monin, C. (2011). L'intégration territoriale du tourisme rural diffus: complémentarité agricole et ancrage social - étude de cas en Auvergne. Migrations et territoires, $48^{e}$ Colloque de l'Association de Science Régionale de Langue Française (p. 17). Paris: Laboratoire Dynamiques Sociales et Recomposition des Espaces.

[18] McGehee, N. \& Kim, K. (2004). Motivation for agri-tourism entrepreneurship. Journal of Travel Research, 43(2), 161-170. Doi: 10.1177/0047287504268245.

[19] Nickerson, N., Black, R. \& McCool, F. (2001). Agritourism: Motivations behind Farm/Ranch Business Diversification. Journal of Travel Research, 40(1), 19-26. Doi: $10.1177 / 004728750104000104$.

[20] Nilsson, P. A. (2002). Staying on farms. An ideological background. Annals of Tourism Research, 29(1), 7-24. Doi: 10.1016/S0160-7383(00)00081-5.

[21] Novelli, M., ed. (2005). Niche tourism: contemporary issues, trends and cases. Oxford: Elsevier Butterworth-Heinemann. 
[22] Odum, E. P. (1959). Fundamentals of ecology. Philadelphia: W. B. Saunders Co.

[23] Phillip, S., Hunter, C. \& Blackstock, K. (2010). A typology for defining agritourism, Tourism Management, 31(6), 754-758. Doi: 10.1016/j.tourman.2009.08.001.

[24] Roberts, L. \& Hall, D. (2001). Rural Tourism and Recreation: Principles to Practice. Wallingford: CABI.

[25] Schmitz, S. (2013). A 'Dutch vision' of Community Based Tourism: Dutch People in the Belgian Ardennes. In Cawley, M., Bicalho, A.M., Laurens, L., eds., The Sustainability of Rural Systems: global and local challenges and opportunities. Galway: Whitaker Institute.

[26] Sharpley, R. \& Vass, A. (2006). Tourism, farming and diversification: An attitudinal study, Tourism Management, 27(5), 1040-1052. Doi: 10.1016/j.tourman.2005.10.025.

[27] Sznajder, M., Przezborska, L. \& Scrimgeour, F. (2009). Agritourism. Wallingford: CAB International.

[28] Tew, C. \& Barbieri, C. (2012). The perceived benefits of agritourism: The provider's perspective. Tourism Management, 33(1), 215-224. Doi: 10.1016/j.tourman.2011.02.005.

[29] Van der Ploeg, D. J., Renting, H., Brunori, G., Knickel, K., Mannion, J., Marsden, T., De Roest, K., Sevilla-Guzmán, E. \& Ventura, F. (2000), Rural Development: From Practices and Policies towards Theory. Sociologia Ruralis, 40(4), 391-408. Doi: 10.1111/14679523.00156.

[30] Van Hecke, E., Antrop, M., Schmitz, S., Van Eetvelde, V. \& Sevenant, M. (2010). Atlas de Belgique - Paysages, monde rural et agriculture. Gent: Academia.

[31] Yang, Z., Cai, J. \& Sliuzas, R. (2010). Agro-tourism enterprises as a form of multi-functional urban agriculture for peri-urban development in China. Habitat International, 34(4), 374385. Doi: 10.1016/j.habitatint.2009.11.002. 